\title{
Transformation of the State Security in the Slovak Republic from 1989 to 1992
}

\section{Jozef Stieranka and Martina Binderová}

Academy of the Police Force in Bratislava, https://www.akademiapz.sk/en

\begin{abstract}
This article describes the main steps of the post-communist transition of the intelligence and counter-intelligence services of the Czechoslovak Socialist Republic, first to the purposes of democratization of the federal formation and then to the establishment of the respective capacity of the Slovak Republic. The authors pay particular attention to the introduction of norms and practices of parliamentary oversight of the security services in this early phase of the transformation process.
\end{abstract}

Keywords: intelligence, counterintelligence, transformation, democratic control, oversight, Slovakia.

\section{Introduction}

The following article describes the transformation process of the State Security (hereinafter StB) ${ }^{1}$ in the Slovak Republic, which began after the "Velvet Revolution" in November 1989. Following the "Velvet Revolution," a democratization process was initiated in all areas of social life, including political, economic, social, as well as changes in the security services. Those changes aimed to set up new security agencies (including intelligence services) to perform their activities on completely different bases compared to the State Security. This study examines two periods, namely a period before the "Velvet Revolution" (until November 1989) and a period of security services transformation (from November 1989 to the end of 1992). Within the first period, the StB organization and management are analyzed, including, in detail, the related legislation, tasks, and powers

1 Štátna bezpečnost', State Security in Slovak. The State Security was an organizational part of the National Security Corps. De facto, it was a police component comprehensively engaged in intelligence and counter-intelligence activities. 
of various State security units shortly before the "Velvet Revolution." The second part of the study deals with the process of the StB transformation in the territory of the Slovak Republic, describing the genesis of necessary legislative changes, as well as assembling the staff of the new intelligence agencies.

\section{The First Period: Organization, Management and the Role of the State Security before November 1989}

When beginning an analysis of this period, it should be noted that in the time before and during the Velvet Revolution in November 1989, the Slovak Republic was part of the Czechoslovak Socialist Republic (hereinafter CSSR). From the aspect of the state and legal establishments, it was a federation of two republics, namely the Czech Socialist Republic (hereinafter CSR) and the Slovak Socialist Republic (hereinafter SSR). Within the federal establishment, some areas of social, political, and economic life, as well as some security issues, came under the authority of the federal ministries of the CSSR. The legal basis for the activities of the National Security Corps (the then "police") before November 1989 was Act No. 40/1970 Coll. on the National Security Corps of April 24, 1974. This applied to the whole territory of the Czechoslovak Socialist Republic and, therefore, it applied to the territory of the SSR as well. The Act came into force on July 1, 1974, and in accordance with Section 1 of the Act, the National Security Corps was a single armed security corps whose primary mission was to protect the socialist state, the social establishment, public order, and the security of persons and property. It fulfilled its tasks through preventive and educational activities and by means of state coercion. The National Security Corps was divided into the State Security and Public Security. The National Security Corps was, in principle, organized by regions, districts, and precincts. Departments operating within the State Security were subordinated to the Federal Minister of Interior of the CSSR. In contrast, departments working in the field of Public Security were subordinated to national Ministers of Interior, i.e., to the Minister of Interior of the SSR in the territory of the Slovak Republic, and to the Minister of Interior of the CSR in the Czech Republic. The duties of both the State Security and the Public Security were assigned in Act No. 40/1970 Coll., Section 4.

State Security tasks included, in particular:

- to detect and eliminate hostile activities against the CSSR;

- to gather and process information relevant to state security and its political and economic development;

- to ensure the protection of constitutional officials;

- to provide, to a limited extent, the protection of particularly significant premises;

- to participate in the defense of the CSSR and in the protection of national borders; 
- to participate in tasks assigned by regulations for the protection of the state, economic, and official secrets.

Tasks of the Public Security were as follows:

- to ensure the safety of persons and property;

- to detect felonies, minor offenses and to identify offenders;

- to investigate and detect offenses and clear them up according to the Criminal Procedure Code;

- to ensure public order and, if disturbed, take measures to restore it;

- to take part in traffic control and to supervise its safety and smooth flow;

- to detect and clarify minor offenses;

- to fulfill tasks assigned in protective supervision.

The accomplishment of tasks by the StB departments was part of the responsibilities of the Federal Ministry of Interior of the CSSR. The State Security organizational structure was built up with regards to this purpose and could be changed in compliance with its needs since, according to Section 8 of Act No. 40/1970 Coll., the organization of the National Security Corps departments managed by the Minister of Interior of the CSSR was set up by the Minister of Interior of the CSSR (Federal Minister of the Interior). One year before the "Velvet Revolution," specifically from August 1, 1988, to February 15, 1990, the StB organizational structure, subordinated to the Federal Ministry of Interior, looked as follows:

- 1st Directorate of the National Security Corps (Main Intelligence Service);

- 2nd Directorate of the National Security Corps (Main Counter-Intelligence Service);

- 3rd Directorate of the National Security Corps (Main Military CounterIntelligence Service);

- $\quad 4$ th Directorate of the National Security Corps (Surveillance);

- 5 th Directorate of the National Security Corps (Protection of Party and Constitutional officials);

- 6th Directorate of the National Security Corps (Intelligence Equipment);

- 12th Directorate of the National Security Corps (Counter-Intelligence Service in Bratislava);

- $\quad$ 13th Directorate of the National Security Corps (Special Directorate);

- Directorate of State Security Investigation;

- Passport and Visa Directorate; 
- Directorate of Automation Development of the National Security Corps. $^{2}$

This study aims to concentrate only on the specialization and tasks performed by operational departments of intelligence and counter-intelligence services in the CSSR.

\section{Main Intelligence Service}

The 1st Directorate of the National Security Corps carried out activities aimed at ensuring the safety and strengthening the defensive capability of the CSSR and the socialist community countries. This would be achieved by specific means, methods, and forms of work. 1st Directorate of the National Security Corps detected and eliminated subversive activities of hostile special services, treacherous emigration, ideological diversion centers, and took measures for the protection of economic interests, developing the economy of the CSSR and socialist countries, and the development of science, technology, and the military. ${ }^{3}$ The following tasks were fulfilled in the above-mentioned focus areas:

- gathering confidential information on the enemy's intentions, plans, and actions against the CSSR and socialist countries, on the enemy's military and economic potential, as well as information and knowledge enabling active fight against external threats;

- collecting, verifying, analyzing, and processing the information obtained by means of intelligence activities and additional resources;

- conducting secret operations and actions in order to support the struggle for global peace, paralyze and weaken the enemy's activities with the aim of strengthening the defense capacity and security of the CSSR and the socialist community in the political, ideological, and economic spheres;

- defending the designated Czechoslovak embassies, institutions, Czechoslovak citizens and residences of the 1st Directorate of the National Security Corps abroad;

- $\quad$ performance of tasks, within its scope, which arose from mutual agreements on cooperation between allied intelligence services;

- $\quad$ ensuring the security of the courier and enciphered connection with all Czechoslovak embassies abroad. ${ }^{4}$

2 "Štruktúra ŠtB [StB Structure]," accessed January 15, 2019, http://www.policie.cz/ clanek/struktura-stb.aspx.

3 “Organizačný poriadok Hlavnej správy rozviedky ZNB [Establishment plan of the Main Directorate of Counter-Intelligence of the National Security Corps]," accessed January 15, 2019, http://www.upn.gov.sk/utvary-stb-a-ps-na-slovensku/1-sprava/zakladneulohy.php.

4 lbid. 


\section{Main Counter-Intelligence Service}

The 2nd Directorate of the National Security Corps, Main Counter-Intelligence Service of the National Security Corps was formed during the reorganization of the Federal Ministry of Interior on October 1, 1988, by merging the former directorate for the fight against the external enemy (formerly the 2 nd Directorate of the Federal Ministry of Interior), the directorate for combatting the interior enemy (formerly the 10th Directorate of the Federal Ministry of Interior) and the directorate for the protection of the economy (formerly the 11th Directorate of the Federal Ministry of Interior).

The 2nd Directorate of the National Security Corps was divided into:

Departments specializing in the fight against the so-called external enemy:

- $\quad 1 s t$ Department - specializing in the USA and Latin American countries;

- 2nd Department - specializing in Germany and Austria;

- 3rd Department - specializing in the United Kingdom, France, and other NATO states; protection of the Federal Ministry of Foreign Affairs;

- 4th Department - specializing in African-Asian countries, terrorism, people smuggling organizations, protection of Soviet troops.

Departments for the protection of economy:

- 5th Department, focused on the pre-production sphere, industry, agriculture;

- 6th Department - aimed at protecting the Federal Ministry of Foreign Trade, foreign trade companies, business representation of foreign companies;

- 7th Department, targeting transport, communications, power engineering;

- 8th Department - focused on the protection of state, economic, and business secrets.

Departments for combatting internal enemies:

- 9th Department - focused on churches, religious societies, sects;

- 10th Department - focused on counter-intelligence on hostile groupings (right-wing and anti-socialist forces, former communists, independent initiatives, Charter 77, Movement for Civil Freedom, Party of Democratic Socialism);

- 11th Department - focused on the youth, science, education, and culture; 
- 12th Department - specializing in ideological diversion centers and emigrant organizations. ${ }^{5}$

In accordance with the Establishment Plan for the Main Directorate of Counter-Intelligence of March 15, 1989, the Directorate was assigned the following main tasks:

- detection of hostile activities by intelligence agencies in the territory of the CSSR;

- detection of hostile activities performed by citizens of the CSSR and foreigners in contact with foreign intelligence services;

- detection, prevention, and elimination of hostile activities performed by persons threatening the internal order of the CSSR;

- implementation of counter-intelligence measures against ideological diversion;

- implementation of counter-intelligence protection of designated premises;

- cooperation with the counter-intelligence agencies aimed at the penetration of hostile intelligence services centers (including participation in so-called disinformation);

- $\quad$ participation in the protection of the state secrets of the CSSR;

- co-operation with the military counter-intelligence service in the protection of military premises (including places in which Soviet troops were deployed);

- application of preventive and educational measures aimed at the prevention or elimination of hostile activities;

- $\quad$ prevention of terrorist activities in the territory of the CSSR;

- $\quad$ penetration of embassies and detection of spies. ${ }^{6}$

On the Slovak Socialist Republic territory, the State Security departments were supervised by the Federal Ministry of Interior. The organization of the StB departments in the territory of the Slovak Socialist Republic was compliant with the territorial-administrative division into three regions, namely the Western Slovak Region, the Central Slovak Region and the Eastern Slovak Republic. The StB departments were divided into:

- State Security Administration Bratislava;

- State Security Administration Banská Bystrica;

- $\quad$ State Security Administration Košice;

5 “Druhá správa ZNB [Second Directorate of the National Security Corps]," January 15, 2019, http://www.cdtr.cz/cs/slovnik/2-sprava-fmv.

6 Ibid. 
- Intelligence departments (Regional Departments of the First Directorate in Slovakia),

which were part of the regional administrations of the National Security Corps. Each StB administration was then divided into three departments. The first department specialized in counter-intelligence protection against the activities of foreign intelligence agencies. The second department was focused on the fight against the so-called internal enemy, and the third department was responsible for the protection of economic interests. Methodological management and supervision over individual departments were exercised by relevant directorates of the Federal Ministry of Interior. The 2nd Directorate of the National Security Corps was responsible for the first department, while the second department was directed by 10th Directorate of the National Security Corps and the third department by the 11th Directorate of the National Security Corps. Following the organizational changes in October 1988, when 2nd, 10th, and 11th directorates of the National Security Corps merged into the Main Counterintelligence Directorate of the Federal Ministry of Interior, all three departments were methodically guided and supervised by the Main Directorate. Regional StB departments were subordinated to the StB deputy chiefs of the Regional Administration of the National Security Corps. The Chief of the 1st Directorate of the National Security Corps provided their methodical management, scrutiny within a specified scale, and ensured officers' training. ${ }^{7}$

As a state coercion body, the main focus of the StB Administration was on prevention, detection, and disruption activities in its assigned territory, i.e., in a particular region. Its activities in a specific region focused mainly on:

- detection of the enemy's intentions in order to prevent their activities, foil their actions, search for and punish their screening counter-intelligence officers and enemy agencies on the territory of the CSSR;

- detection and thwarting of hostile activities of emigrant, Zionist, nationalist, and other anti-socialist centers, organizing ideological diversion and other hostile activities against the CSSR and socialist countries;

- detection and recording of anti-state activities carried out by persons from among internal enemies, anti-socialist clusters, and wrecking enemy activities;

- ensuring the agency and operational protection of special important premises that might be of interest to enemy intelligence services; the State Security participated in the protection of classified information in other designated premises;

7 "Útvary rozviedky na území SSR [Counter-intelligence Departments in the Territory of the Slovak Socialist Republic]," January 15, 2019, http://www.upn.gov.sk/utvary-stba-ps-na-slovensku/1-sprava/utvary-rozviedky.php. 
- detection, recording and prevention of foreigners' cross-border activities and cooperation in the protection of national borders;

- $\quad$ exercising the agency-operative supervision over returned émigrés and foreigners permanently residing on the territory of the Czechoslovak Socialist Republic;

- $\quad$ prevention of improper travel of Czechoslovak citizens abroad through agency-operational means;

- $\quad$ providing the external protection of premises of the Czechoslovak People's Army and Soviet troops in specified places. $^{8}$

\section{Regional Structures}

In compliance with its specializations, the State Security administration of the relevant regional directorate of the National Security Corps fulfilled the following tasks:

- it organized and implemented the detection of anti-state activities in the territory of a region through agents and operational means, keeping and processing operational records. It decided about the investigation of a case, except for the cases requiring approval by the Chief of the Main Counter-Intelligence Directorate or the Regional Administration of the National Security Corps;

- in cooperation with national and economic authorities in the territory of a region, it organized the protection of state, economic, and service/ official matters;

- it gathered and analyzed information on the operational situation in individual issues and premises in the territory of a region, on the scope and level of the cases and signals being worked on, the scope and level of the means of the operational work (agency system, monitoring, operational technology), their distribution and use in the territory of a region;

- it organized the performance of the service by border control departments in the region;

- it organized preventive measures in line with the Main Counter-Intelligence Directorate's plan and within its scope of authority;

- it kept statistics and registries of the agency-operational nature within a region;

- it was responsible for the effective distribution of work among individual departments within the StB framework. In addition, it cooperated with

8 "Správa ŠtB KS ZNB [StB Administration of the Regional Administration of the National Security Corps]," January 15, 2019, http://www.upn.gov.sk/utvary-stb-a-ps-naslovensku/sprava-stb-bratislava/zakladne-zameranie.php. 
the territorial authorities of military counter-intelligence and, in cases extending beyond the region, also with other StB administrations;

- $\quad$ in accordance with the principles of the notification service, it informed the Chief of the Main Counter-intelligence Directorate and the Chief of the Regional Administration of the National Security Corps, especially about important new knowledge of anti-state activities within individual cases and the progress of their elaboration, work results, and the stateof-the-art and needs of the professional and political training of officers;

- it performed operational activities according to the orders and directives of the Chief of the Main Counter-intelligence Directorate and the Chief of the Regional Administration of the National Security Corps and methodological instructions of the Main Counter-Intelligence Directorate. $^{9}$

In addition, there were two more StB departments operating in the territory of the Slovak Socialist Republic:

- The 12th Directorate of the National Security Corps - Counter-intelligence Directorate in Bratislava;

- The intelligence department of the 11 th Border Guard Brigade. ${ }^{10}$

The 12th Directorate of the National Security Corps - Counter-intelligence Directorate in Bratislava was a unit of the National Security Corps and a component of State Security. As an executive unit of the Federal Ministry of Interior, it was responsible for ensuring, implementing and organizing counter-intelligence measures on designated issues and in federal premises within the territory of the Slovak Socialist Republic. It was divided into:

- $\quad$ 1st Department - department for combatting the external enemy;

- 2nd Department - department of the fight against internal enemies;

- 3rd Department - department for the protection of the economy;

- 4th Department - surveillance department;

- 5th Department - screening of correspondence and expertise department;

- $\quad 6$ th Department - intelligence equipment department. ${ }^{11}$

The Department for Combatting the External Enemy took counter-intelligence measures against the penetration of special services in the Czechoslovak Socialist Republic. It worked in the premises of the Diplomatic Corps Services

9 Ibid.

10 "Spravodajské zložky 11. brigády PS [Intelligence Units of the 11th Border Guard Brigade]," January 15, 2019, http://www.upn.gov.sk/sk/utvary-a-prislusnici-stb-a-ps/.

11 "XII. Správa ZNB [12th Directorate of the National Security Corps]," January 15, 2019, http://www.upn.gov.sk/utvary-stb-a-ps-na-slovensku/12-sprava/index.php. 
Directorate, the UN Research Computing/Computational Centre, the United Nations Environment Protection Research Centre, Press and Information Centre of the Federal Ministry of Foreign Affairs, and the embassies of capitalist states, China and Yugoslavia. It worked on cases and signals in the following issues: Diplomats, Travel Agencies, Foreign Visas, and Excursions/ Travels.

\section{Combatting Internal Enemies}

The Division for Combatting Internal Enemies was broken down into:

- 1 1st department, dealing with right-wing opportunism issues;

- 2nd department, dealing with culture, science, and mass media matters;

- $\quad 3 r d$ department, dealing with education, youth, sport issues, protection of national front organizations and revivalist political parties, Zionism and Slovak separatism;

- Special Department, dealing with the issues of the Church and various sects. $^{12}$

\section{Protecting the Economy}

The Division for the Protection of Economy was divided into:

- 1st department, dealing with counter-intelligence protection of the Czechoslovak Foreign Trade and observing foreign trade representative offices in Bratislava, Western companies' branches, international fairs and exhibitions held in Bratislava (especially in INCHEBA), the penetration of foreign intelligence services and monopolies into central sectors of the Czechoslovak economy;

- 2nd department, dealing with sections of counter-intelligence protection of the scientific research base, planning and financing of the national economy, investment, construction, design and management, computing technology and environment, chemical industry, agriculture and nutrition, building and investment construction and internal trade in terms of counter-intelligence protection of the pre-production and production spheres;

- $\quad 3 r d$ department, ensuring the protection of classified information in central organizations of the Slovak economy and carrying out screening of persons proposed for getting access to state secrets.

12 "XII. Správa ZNB, popis odborov [12th Directorate of the National Security Corps, description of departments]," January 15, 2019, http://www.upn.gov.sk/utvary-stb-aps-na-slovensku/12-sprava/popis-odbor-2.php. 
The Division for the Protection of the Economy worked on the so-called economic right, ensuring the counter-intelligence protection of socialist development and protection of the Council for Mutual Economic Assistance. ${ }^{13}$

\section{Border Guards}

The main task of the intelligence unit of the 11th Border Guard Brigade and its subordinate intelligence groups (1. Malacky, 2. Bratislava, 3. Komárno) was to gather and evaluate information on persons planning their escape abroad and related counter-intelligence tasks. Intelligence activities were carried out by the Intelligence Directorate of the Main Administration of the border guard of state border protection, a superior unit in powers/authority to the 11th Border Guard Brigade. The intelligence structure of the 11th Border Guard Brigade was extended by the intelligence group Petržalka from 1 November 1979. ${ }^{14}$

\section{The Second Period: The Transformation of the Security Agencies after the "Velvet Revolution," November 1989 - end of 1992}

On a federal level, the transformation of the State Security agencies after the "Velvet Revolution" did not take place in a single step. It was implemented through gradual changes in the organization, legislation, and staffing of the new security services. The main events of the transformation process were:

- The dissolution of all StB departments by February 15, 1990 (by the Federal Minister of Interior Order No. 16 and No. 17 of January 31, 1990);

- The establishment of the Office for the Protection of the Constitution and Democracy of the Federal Ministry of Interior by the Federal Minister of Interior order. The Office functioned from February 16, 1990, to December 19, 1990;

- The establishment of the Federal Intelligence Service by order of the Federal Minister of Interior. It operated from December 20, 1990, to June 30, 1991;

- The creation of the Federal Security Intelligence Service by Act No. 244/ 1991 Coll. on the Federal Security Service and the Use of intelligence means. The service operated from July 1, 1991, to December 31, 1993;

- The establishment of the Service for the Protection of Economic Interests in the Czech Republic and the Slovak Republic.

Immediately after the "Velvet Revolution," democratization and transformational changes began in all areas of social life. In the beginning, there were political and economic changes. Of course, the changes also concerned the armed

13 Ibid.

14 "Spravodajské zložky 11. brigády PS [Intelligence Units of the 11th Border Guard Brigade]," January 15, 2019, http://www.upn.gov.sk/utvary-stb-a-ps-na-slovensku/11brigada/. 
security corps, which had been discredited by its "forceful" intervention against the participants of the November demonstrations. Due to that, the newly-originated political parties and movements (the Citizens' Forum in the Czech Republic and The Public against Violence in the Slovak Republic), which formed a government of national understanding, took over the implementation of changes in the field of security services. During the first phase, all StB activities ceased, and its members could not carry out their duties anymore. At the same time, civilian screening commissions ${ }^{15}$ were created in each region by order of the Federal Minister of Interior. The aim of the commissions was to interview each member of the State Security and consider their previous work activities and assess their capability to work in the new security services. The purpose of the "civilian reviews" was to independently assess which State Security members would be able to continue to work for the newly created security and intelligence services.

The Civilian Commissions were composed of representatives of the main political parties - the Citizens' Forum and the Public against Violence. In addition, members of the Public Security and so-called reactivated former members of the National Security Corps who had been dismissed from service after 1968 were appointed to those commissions. Some politicians were of the opinion that the commissions were created too hastily, often from randomly selected people who did not have adequate knowledge of the activities performed by individual officers, and that this resulted in insubstantial screening. ${ }^{16}$ Some politicians adhered to the view that former StB members should not be admitted to the new security and intelligence services. Others believed that it would be a mistake to dismiss all intelligence and counter-intelligence officers and not make use of their experience in the new intelligence services as long as the civilian commission had assessed them as reliable and competent for the work in the new intelligence services. One of the arguments was that there was a risk that the former officers might be recruited by foreign intelligence and other services. ${ }^{17}$

On February 15, 1990, Richard Sacher, the Federal Minister of the Interior, abolished all StB components and ensured that new departments would be created on their foundations. The Intelligence Service (First Directorate of the National Security Corps of the Federal Ministry of Interior) changed into the Office for Foreign Relations and Information of the Federal Ministry of Interior. Together with its headquarters, the new office took over all of its registries and archives, and a large number of the employees in the First Directorate of the National Security Corps. The Second Directorate of the National Security Corps-

15 Order of the Minister of the Interior of CSSR 21 of 7 February 1990, accessed January 21, 2020, https://www.ustrcr.cz/data/pdf/rozkazy/rfmv90-92/21-90.pdf.

16 Vladimír Palko, "November ešte neznamenal koniec, Štátna bezpečnost' prežila dodnes [November did not mean the end, State Security has survived to this day]," SME.sk, December 13, 2001, www.sme.sk/c/184683/november-este-neznamenalkoniec-statna-bezpecnost-prezila-dodnes.html.

17 Palko, "November ešte neznamenal koniec." 
The Main Directorate of Counter-intelligence-was transformed into the Office for the Protection of the Constitution and Democracy similar to Germany's model, and became part of the Federal Ministry of Interior. The Office for the Protection of the Constitution and Democracy was established from the previous four State Security directorates: Counterintelligence (Second Directorate of the National Security Corps), Slovak Counterintelligence (12th Directorate of the National Security Corps), Surveillance (4th Directorate of the National Security Corps) and Intelligence Equipment (6th Directorate of the National Security Corps). The 4th Directorate of the National Security Corps (Military Counterintelligence) was transformed into the Military Defense Intelligence as part of the Federal Ministry of Defense. The Federal Office for the Protection of Constitutional Officials was created from the 5th Directorate of the National Security Corps - Protection of State Officials. ${ }^{18}$ These newly-formed units hired former State Security officers who had passed the reviews by civilian commissions, on the one hand, and some of the officers who had been dismissed from service during the 1970s purges, on the other. The remainder was made up of new employees who were intended to gradually replace the former StB officers.

On December 9, 1990, the Office for the Protection of the Constitution and Democracy was dissolved by order of the Federal Minister of Interior, and the Federal Information Service of the Federal Ministry of Interior was established. All former StB officers, including the ones who had undergone civil commission reviews in 1990, were prevented from joining the service. ${ }^{19}$ The Federal Information Service was abolished on June 30,1991, by order of the Federal Minister of Interior. In fact, supervision over the newly created intelligence services did not exist in that period.

On July 1, 1991, the Federal Security Information Service was established. It operated until the termination of the Czech and Slovak Federal Republic at the end of 1992. The establishment of the Federal Security Information Service is considered to be the beginning of a new era in the legal regulation and actual activity of intelligence services in Czechoslovakia, because unlike the Office for the Protection of the Constitution and Democracy and the Federal Information Service of the Federal Ministry of Interior, it did not arise by order of the Federal Minister of Interior, but by the Act of the Federal Assembly No. 244/1991 on the Federal Security Service and the Use of Intelligence Equipment. This Act made the Federal Security Information Service an independent authority that did not fall under the Federal Ministry of Interior, as was the case of the Office for the Protection of the Constitution and Democracy and the Federal Information Service of the Federal Ministry of Interior. The Act already incorporated both the basic democratic principles and the principles of intelligence services (including their oversight) that was similar to other democratic countries. The Act fully accepted the principle of legality and constitutionality. The Federal Security Infor-

18 Palko, "November ešte neznamenal koniec."

19 Palko, "November ešte neznamenal koniec." 
mation Service Act defined precisely the specific areas of authority and instituted parliamentary oversight of Service's activities. The Act laid down the conditions for the legitimate use of intelligence means and explicitly defined and stipulated the legal conditions under which those means could be used. Contrary to the State Security activities, the Act did not give executive powers of a police nature, such as investigative competencies, to the Federal Security Information Service officers.

Under Section 2, the Federal Security Information Service was responsible for collecting, collating, and evaluating information that was:

- important for the protection of the constitutional establishment;

- derived from the activities of foreign intelligence services;

- concerning terrorism organized in connection with foreign countries;

- directed against state security and important for the protection of state economic interests. ${ }^{20}$

The service was able to make the gathered information available to the President of the Czech and Slovak Federal Republic, to three governments (the Czech and Slovak Federal Republic Government, the Czech Republic Government, and the Slovak Republic Government) and the three parliaments (the Federal Assembly, the Czech National Council, and the Slovak National Council). Intelligence could also be passed to other state authorities, if needed, for the prevention of unconstitutional and illegal activity. ${ }^{21}$

To gather and evaluate the information in the above-mentioned areas of operation, the Federal Security Information Service was authorized to use the following intelligence means:

- intelligence technology;

- covert means and documents;

- surveillance;

- $\quad$ persons acting in favor of the Federal Security Information Service. ${ }^{22}$

The intelligence equipment could only be used by the Federal Security Information Service in its jurisdiction on the basis of a prior written authorization by the Prosecutor, and only in cases where the detection and recording of the activities were otherwise ineffective or substantially constrained. The Prosecutor could set the duration of the use of intelligence equipment up to a maximum period of six months. This time could be extended on the basis of a new application, each time for no longer than six months. Information obtained through the use of the intelligence equipment could only be used by the Federal Security In-

20 Act No. 244/1991 on the Federal Security Information Service and Use of Intelligence Means, Section 2.

21 Act No. 244/1991, Section 3.

22 Act No. 244/1991, Section 14. 
formation Service and in compliance with the provisions on keeping records on individuals. For the purposes of this Act, the technical-intelligence measures were primarily electro-technical, radio-technical, photo-technical, optical, mechanical, chemical, and other technical measures and equipment or their sets, used in a covert manner in:

a) searching for, opening, examining, and assessing mail and other transported packages suspected of being used for criminal purposes;

b) monitoring and recording of telecommunication activities;

c) production of visual, audio, audio-visual and other recordings in cases in which the Federal Information Service has used them to discover information within the scope of its competences. ${ }^{23}$

The activities of the Federal Security Information Service were subject to parliamentary scrutiny. Authorization to carry out the scrutiny was given by the Federal Assembly, which set up a specialized oversight body for that purpose. ${ }^{24}$ The oversight body consisted of three to four members elected by the People's House from among its deputies, and three to four deputies elected by the House of Nations. If the oversight authority had doubts about the legality of the Federal Security Information Service's activities, it was entitled to ask the Director for the necessary justification. The oversight body was also empowered to order the Director to terminate any activity that went beyond the scope of the Service or was illegal. The body was also authorized to request all the data within Federal Security Information Service records, which were beyond the Service's province, were untrue, or which had been obtained unlawfully, to be stored so that no one, except for the court, could access them. Any violation of the law by Federal Security Information Service officers that was discovered by the oversight body was to be notified to the Federal Assembly and the General Prosecutor of the Czech and Slovak Federal Republic. Depending on the nature of the matter, the government of the Czech and Slovak Federal Republic was also to be notified. ${ }^{25}$

As a result of the division of the Czech and Slovak Federal Republic into two separate states - the Czech Republic and the Slovak Republic - the Federal Security Information Service was disbanded by Act No. 543/1992 Coll. on the Federal Security Information Service. ${ }^{26}$ In particular, this Act dealt with the division of immovable and movable property and property rights and obligations, including the right to the economic management of the Federal Security Information Service, between the Czech Republic and the Slovak Republic (in the ratio of two to one). Next, it solved the division of the information stored in databases, the

23 Act No. 244/1991, Section 15.

24 Act No. 244/1991, Section 5.

25 Act No. 244/1991, Section 7.

26 Law 543 on the Abolition of the Federal Security Information Service, November 13, 1992, https://www.slov-lex.sk/static/pdf/1992/543/ZZ_1992_543_19921231.pdf (in Slovak). 
handing over of records, and sorting out of service and labor-law relations. The information from the Federal Security Information Service databases was divided between the competent authorities of the Czech and Slovak Republics under an agreement concluded between the authorities while respecting the state security interests of both republics.

The then Prime Minister of the Slovak Republic, Vladimír Mečiar, did not trust the federal intelligence organizations (Office for the Protection of the Constitution and Democracy, Federal Information Service of the Federal Ministry of Interior, Federal Security Information Service) during the transformation period (from 1990 to 1992). Efforts were made to remove some competencies from the federal government of the Czech and Slovak Federal Republic and hand them over to the national governments. There also occurred a demand for the creation of national secret services, so that the Slovak Republic and the Czech Republic would have their own independent intelligence services. Some Slovak politicians, including Vladimír Mečiar, argued at the time that "it was not possible for the Prime Ministers or Speakers of National Councils to be dependent on one's goodwill whether they obtain information on the national political and security situation in their territory from federal security forces." 27 The objections were partially removed by establishing intelligence services in the Slovak Republic and in the Czech Republic within the control of the national Ministries of Interior (the Czech Ministry of Interior and the Slovak Ministry of Interior) whose powers were narrowed only to the area of the protection of national economic interests. This step was mainly undertaken with the purpose of preventing fraud and other illegal activities in the transformation of economies, specifically the ongoing privatization of state property. Based on these arguments, services for the protection of economic interests within the competence of national police forces were established in both the Slovak Republic and in the Czech Republic in April 1991.

In the Slovak Republic, the Service for the Protection of Economic Interests was legally established by Act No. 204/1991 on the Police Force of the Slovak Republic (Annex 8). ${ }^{28}$ Following Section 4 (3) of the Act, this Service was created as a special service of the Police Force. The Service for the Protection of Economic Interests was not subordinated to the President of the Police Force like other organizations such as the criminal police, traffic police, public-order police, and premises protection service, but was directly responsible to the Minister of the Interior. The duties of the Service for the Protection of Economic Interests were, according to Section 3 (1c), to collect, summarize and evaluate information important for the protection of economic interests of the Slovak Republic. To fulfill their tasks, officers had, in addition to the ordinary powers of a member of

27 Palko, "November ešte neznamenal koniec."

28 Law 204 on the Police Force of the Slovak Republic, April 29, 1991, https://www.slovlex.sk/static/pdf/1991/204/ZZ_1991_204_19920101.pdf (in Slovak). 
the Police Force, special powers mentioned in Title 3 of the Act, especially the means of operative-search activity and technical-intelligence means. ${ }^{29}$

For the purposes of this Act, the means of operational search activity included the following:

- surveillance of persons and objects;

- use of covert means and documents;

- decoy and safeguarding equipment; and

- the use of persons acting in favor of service for the protection of economic interests. ${ }^{30}$

The means and conditions for the use of technical intelligence were defined correspondingly in the intelligence technology Act No. 244/1991 Coll. on the Federal Security Service and the Use of Intelligence Means.

The fourth title of Act No. 204/1994 Coll. on the Police Force also included provisions regarding the distribution of the information obtained by the Service for the Protection of Economic Interests and ways by which the scrutiny of the Service's activities can be ensured. Through the mediation of the Minister of Interior, the Service for the Protection of Economic Interests provided the Slovak National Council and the Government of the Slovak Republic with any information important for their activities and decision-making. This information could also be made available to other national authorities. ${ }^{31}$ The activities of the Service for the Protection of Economic Interests were inspected by the Slovak National Council, which set up a special oversight body for that purpose. The Ministry of Interior of the Slovak Republic was required to submit to the special scrutiny authority any directives regulating the use of operational-search activity and technical-intelligence means by the Service for the Protection of Economic Interests.

\section{Disclaimer}

The views expressed are solely those of the authors and do not represent official views of the PfP Consortium of Defense Academies and Security Studies Institutes, participating organizations, or the Consortium's editors.

\section{About the Authors}

Jozef Stieranka, PhD, is a Professor in the Academy of the Police Force in Bratislava. E-mail: jozef.stieranka@minv.sk

Martina Binderová, a doctor in pedagogy, teaches and conducts research at the Academy of the Police Force in Bratislava. E-mail: martina.binderova@minv.sk

\footnotetext{
29 Law 204/1991, Section 29.

30 Law 204/1991, Section 30.

31 Law 204/1991, Section 35.
} 


\section{Acknowledgment}

Connections: The Quarterly Journal, Vol. 18, 2019 is supported by the United States government. 